\title{
Hepatoprotective and Anti-Hepatitis C Viral Activity of Platycodon grandiflorum Extract on Carbon Tetrachloride-Induced Acute Hepatic Injury in Mice
}

\author{
Tae-Won KIM ${ }^{1}$, Jong-Hwan LIM ${ }^{2 * *}$, In-Bae SONG ${ }^{1}$, Sang-Jin $\mathrm{PARK}^{2}$, Jae-Won YANG ${ }^{2}$, \\ Jung Cheul SHIN ${ }^{2}$, Joo-Won SuH ${ }^{3}$, Hwa-Young SoN ${ }^{1}$, Eun-Sang CHO ${ }^{1}$, Myoung-Seok KIM ${ }^{4}$, \\ Sang-Wook LEE ${ }^{2}$, Jong-Woo KIM ${ }^{2}$ and Hyo-In YuN ${ }^{1}$ \\ ${ }^{1}$ College of Veterinary Medicine, Chungnam National University, Daejeon, \\ 305-764, South of Korea \\ ${ }^{2}$ BEC Biopharm, Advanced Institutes of Convergence Technology, Suwon, Gyeonggi-Do, \\ 443-759, South of Korea \\ ${ }^{3}$ Division of Bioscience and Bioinformatics, Myongji University, Yongin, \\ Gyeonggi-Do, 449-728, South of Korea \\ ${ }^{4} J e o l l a n a m d o$ Development Institute for Traditional Korean Medicine, \\ Jangheung, Jeollanam-Do, 529-851, South Korea
}

(Received July 6, 2011)

\begin{abstract}
Summary The present study aims to evaluate the anti-HCV activity of hotwater extract from Platycodon grandiflorum (BC703) with $\mathrm{HCV}$ genotype $1 \mathrm{~b}$ subgenomic replicon system and investigate its hepatoprotective activity on carbon tetrachloride $\left(\mathrm{CCl}_{4}\right)$-induced acute liver damage in mice. $\mathrm{BC} 703$ produced significant hepatoprotective effects against $\mathrm{CCl}_{4}$ induced acute hepatic injury by decreasing the activities of serum enzymes, nitric oxide and lipid peroxidation. Histopathological studies further substantiated the protective effect of BC703. Furthermore, BC703 inhibited the HCV RNA replication with an $\mathrm{EC}_{50}$ value and selective index $\left(\mathrm{CC}_{50} / \mathrm{EC}_{50}\right)$ of $2.82 \mu \mathrm{g} / \mathrm{mL}$ and above 35.46 , respectively. However, digested $\mathrm{BC} 703$ using a simulated gastric juice showed poor protective effect against $\mathrm{CCl}_{4}$-induced hepatotoxicity in mice and decreased anti-HCV activity as compared to the intact $\mathrm{BC} 703$. Although further studies are necessary, $\mathrm{BC} 703$ may be a beneficial agent for the management of acute hepatic injury and chronic HCV infection.
\end{abstract}

Key Words Platycodon grandilorum, carbon tetrachloride, hepatotoxicity, hepatitis C virus

Herbal medicines that have been used in China for thousands of years are now being manufactured in Korea as drugs with standardized quality and quantities of ingredients. The roots of Platycodon grandiflorum have been consumed as a foodstuff and as a folk remedy for diseases such as bronchitis, asthma, pulmonary tuberculosis and inflammation (1). It was reported to contain a lot of carbohydrates (at least $90 \%$ ), protein $(2.4 \%)$, lipids $(0.1 \%)$ and ash (1.5\%) (1). Recently, it has been reported that the polysaccharides isolated from the root of Platycodon grandiflorum prevent obesity, hypecholesterolemia, hypertension, diabetes, immune modulation and hyperlipidemia (2-5). In addition, triterpenoid saponins in the roots of the Platycodon grandiflorum are believed to prevent chemical-induced hepatotoxicity $(6,7)$. In our previous study, the standardized aqueous extract of Platycodon grandiflorum was shown to attenuate thioacetamide-induced fulminant hepatic failure in mice (5). Although the beneficial effect of Platycodon graniflorum on acute hepatic failure using various chemical induced hepatic injury models has been widely studied, little is known about the preventa-

*To whom correspondence should be addressed.

E-mail: jhlim99@bncbio.com tive effect of Platycodon grandiflorum decoction on $\mathrm{CCl}_{4-}$ induced acute hepatic injury in mice. In addition, information on its stability in the stomach has not been investigated and this information may be important to contribute to the development of Platycodon grandiflorum extract, which can later be directed to consumers with an increased knowledge of the content and biological activity of this medicinal herb.

The liver plays a central role in transforming and clearing xenobiotics, and is susceptible to their toxicity (8). Carbon tetrachloride $\left(\mathrm{CCl}_{4}\right)$ has been one of the most intensively studied hepatotoxicants and provides a relevant model for liver damage $(8-10) . \mathrm{CCl}_{4}$ is a potent hepatotoxicant and a single exposure to it can rapidly lead to severe centrizonal necrosis and steatosis (9-12). During its metabolization, an unstable trichloromethyl free radical $\left(\mathrm{CCl}_{3}\right)$ is formed and rapidly converted to trichloromethyl peroxide (9-11). These free radical result in the peroxidation of fatty acids found in the phospholipids making up the cell membranes. Lipid peroxide radicals, lipid hydroperoxides and lipid breakdown products develop in this process and each constitutes an active oxidizing agent. Consequently, cell membrane structures and intracellular organelle membrane structures are completely broken down $(9,10,12)$. 
Hepatitis $\mathrm{C}$ virus (HCV) infection is a major healthcare problem around the world (13). HCV infection usually runs a chronic infection in an estimated $70 \%$ of HCV patients. Approximately 170 million subjects are chronically infected with HCV (13-15). A chronic HCV infection leads to cirrhosis and hepatocellular carcinoma and causes 300,000 deaths per year (13). Current treatment is based on a combination of pegylated interferon (IFN)- $\alpha$ and ribavirin, which directly inhibits $\mathrm{HCV}$ replication and causes progressive infected cell clearance through intricate and only partly understood mechanisms (13-15). Among natural antiviral agents, recent investigations have reconsidered the interest of phyto-polysaccharides, which act as potent inhibitors of different viruses (16-18).

In the present study, the standardized hot water extract from Platycodon grandiflorum was tested for its antiviral properties using a cell-based HCV subgenomic replicon system. We also investigated its protective effect on $\mathrm{CCl}_{4}$-induced acute hepatic injury in mice.

\section{MATERIALS AND METHODS}

Chemicals and reagents. Thiobarbituric acid reactive substances (TBARS), glutathione (GSH), and nitric oxide (NO) assay kits were purchased from BioAssay Systems (Hayward, CA, USA). Serum alanine aminotransferase (ALT) and aspartate aminotransferase (AST) test kits were obtained from IDEXX Laboratories (Westbrook, ME, USA). The superoxide dismutase (SOD) assay kit was obtained from Cayman (Ann Arbor, MI, USA). Carbon tetrachloride, Folin-Ciocalteu phenol reagent, 2,2-diphenyl-1-picrylhydrazyl (DPPH) and other chemicals were purchased from Sigma Chemicals (St. Louis, MO, USA). Acetonitrile and methanol as HPLC-grade were obtained from Mallinckrodt Baker (Phillipsburg, NJ, USA).

Preparation of BC703. The standardized Platycodon grandiflorum hot water extract (BC703) was manufactured by SkyHerb Pharmaceuticals (Zhejiang, China) according to full good manufacturing practice (GMP). Briefly, the dried roots of Platycodon grandiflorum were cut into slices and extracted in distilled water with occasional shaking at $60-90^{\circ} \mathrm{C}$ for $6-10 \mathrm{~h}$. The aqueous extract was then filtered, concentrated under reduced pressure in a rotary evaporator and spray-dried into powder.

Simulated gastric juices were prepared by suspending pepsin $(1: 10,000, \mathrm{ICN})$ in sterile saline $(0.5 \% \mathrm{w} / \mathrm{v})$ to a final concentration of $3 \mathrm{~g} / \mathrm{L}$ and adjusting to $\mathrm{pH} 2$, and $\mathrm{BC} 703$ was incubated for $2 \mathrm{~h}$ at $37^{\circ} \mathrm{C}$ for preparation of digested $\mathrm{BC} 703$.

HPLC-ELSD analysis. HPLC analysis of BC703 was carried out as previously described (5). In brief, HPLC analysis of BC703 was performed on a Younglin ACME 9000 (Seoul, Korea) equipped with a Sedex 55 evaporative light scattering detector (ELSD; SEDERE, Alfortville, France). Sample separation was achieved in a Gemini $\mathrm{C}_{18}$ column $(100 \mathrm{~mm} \times 4.6 \mathrm{~mm}, 3 \mu \mathrm{m}$ particle size; Phenomenex, Torrance, CA, USA) with a precolum $\left(\mathrm{C}_{18}, 3.5 \mu \mathrm{m}, 2 \times 20 \mathrm{~mm}\right)$ at room temperature. The mobile phase consisted of $0.1 \%$ formic acid $/$ methanol/ acetonitrile $(75: 5: 20, \mathrm{v} / \mathrm{v} / \mathrm{v} ; \mathrm{A})$ and $0.1 \%$ formic acid/methanol/acetonitrile $(70: 5: 25, \mathrm{v} / \mathrm{v} / \mathrm{v} ; \mathrm{B})$ and gradient runs programed as follows: $0-10 \mathrm{~min}(0 \% \mathrm{~B})$, 10-17 min (0-50\% B), 25-34 min (50-80\% B), 42$52 \min (100 \% \mathrm{~B})$ and then equilibration with $0 \% \mathrm{~B}$ for $10 \mathrm{~min}$ at a flow rate of $1 \mathrm{~mL} / \mathrm{min}$. The injection volume was $20 \mu \mathrm{L}$. The ELSD was set to a probe temperature of $70^{\circ} \mathrm{C}$, a gain of 7 , and the nebulizer gas nitrogen adjusted to 2.5 bar.

Anti-HCV activity in the HCV replicon model of BC703. The plasmid pNNeo/3-5B replicon of Ikeda et al. (19) contains the sequence of a similar $\mathrm{HCV}$ replicon in which almost all of the NS3-NS5B sequence comprising the $3^{\prime}$ cistron is derived from an infectious molecular clone of the genotype $1 \mathrm{~b}$ virus, HCV-N (GenBank accession no. AF139594). It was kindly provided by Prof. Soon-bong Hwang (Ilsong Institute of Life Science, Hanllym University, Anyang, Korea). An expression vector harboring $\mathrm{HCV}$ replicon proceeded to in vitro transcription and the obtained HCV replicon was transfected into the Huh7 cells by electroporation. To select only those cells having the HCV replicon, Huh7 cells were cultured with Dulbecco's modified Eagle's medium (Invitrogen, Carlsbad, CA, USA) supplemented with $10 \%$ of fetal bovine serum, $1 \%$ nonessential amino acids, and $500 \mu \mathrm{g} / \mathrm{mL}$ of geneticin.

$\mathrm{HCV}$ replicon-harboring cells were seeded at a low density of $1 \times 10^{4}$ cells per well in a 96-well plate and maintained at $37^{\circ} \mathrm{C}$ and $5 \% \mathrm{CO}_{2}$. The next day, the culture medium was replaced with medium containing serially diluted compounds in the presence of $2 \%$ FBS and $0.1 \%$ DMSO. After the cells were treated for $72 \mathrm{~h}$, total RNA was extracted using a CellAmp Direct RNA Prep Kit (Korea Biomedical, Seoul, Korea). The HCV RNA levels were quantified by a quantitative real-time polymerase chain reaction assay using an IQ5 real time PCR detection system (Bio-Rad, Hercules, CA, USA) with HCV-specific primers (5'-GACACTCCACCATAGATCACTC-3' and 5'-CCCAACACTACTCGGCTAG-3') and probe (5'-FAM-CCCAAATCTCCAGGCATTGAGCGG-3' BHQ-1). Results were normalized to glyceraldehyde-3phosphate dehydrogenase gene (GAPDH). Each data point represents the average of at least 3 replicates in cell culture. Relative HCV RNA reduction was assessed by comparing the level of HCV RNA in compound treated cells to control cells treated with $0.1 \%$ DMSO.

Cytotoxicity of BC703. The cytotoxicity of BC703 on Huh7 cells was determined. Cell viability was then assessed with a 3-(4,5-dimethylthiazol-2-yl)-2,5-diphenyltetrazolium bromide colorimetric assay. The 50\% cytotoxic concentration $\left(\mathrm{CC}_{50}\right)$, defined as the compound concentration that inhibited proliferation of exponentially growing cells by $50 \%$, was calculated.

Polyphenolic content and DPPH radical scavenging activity. The total phenolic content was determined according to the method described by Slinkard and Singleton (20). The sample was accurately weighed and dissolved in a $100 \mathrm{~mL}$ brown volumetric flask with distilled water. The standard solution of gallic acid (0- 


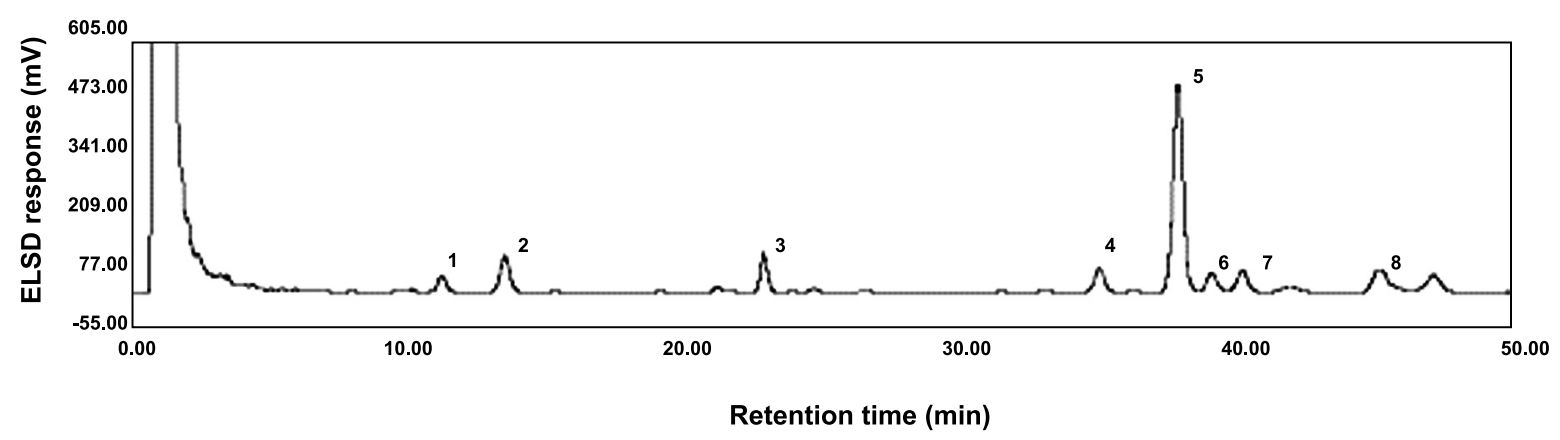

Fig. 1. Representative HPLC chromatograms of triterpenoids from extract of Platycodon grandiflorum and BC703. The numbers indicate each platycoside: 1 , deapioplatycoside $\mathrm{E} ; 2$, platycoside $\mathrm{E} ; 3$, platycodin $\mathrm{D}_{3} ; 4$, platycodin $\mathrm{D}_{2} ; 5$, platycodin $\mathrm{D}$; 6, platycodin A; 7, polygalacin D; 8, 2"-O-acetyl platycodin D.

$0.06 \mathrm{mg} / \mathrm{mL}$ ) was prepared. The standard and the sample $(0.40 \mathrm{~mL}$ each) were mixed with the Folin-Ciocalteu phenol reagent $(0.5 \mathrm{~mL})$ and $20 \%$ of $\mathrm{Na}_{2} \mathrm{CO}_{3}(1.5 \mathrm{~mL})$. The absorbance at $760 \mathrm{~nm}$ was measured $20 \mathrm{~min}$ after incubation at $30^{\circ} \mathrm{C}$ using an ultraviolet-visible spectrophotometer.

The free radical scavenging activity of $\mathrm{BC703}$ was measured using the stable radical DPPH (21). A solution of DPPH $(0.1 \mathrm{mM})$ in ethanol was prepared, and $900 \mu \mathrm{L}$ of this solution was added to $100 \mu \mathrm{L}$ of $\mathrm{BC} 703$ solution at different concentrations (0.05 to $5 \mathrm{mg} / \mathrm{mL})$. The resulting solution was thoroughly mixed by vortexing and left in the dark, and then the absorbance was measured at $517 \mathrm{~nm}$ at different times until the reaction reached a steady state. The scavenging activity was determined by comparing the absorbance with that of the blank. When the reaction reached a plateau, the $\mathrm{IC}_{50}$ value of $\mathrm{BC} 703$ was calculated from the results.

Animals. Male ICR mice, weighing between 32 and $36 \mathrm{~g}$ at the age of 5-6 wk, were used for this study. They were obtained from OrinetBio (Sungnam, Korea) and acclimated for $1 \mathrm{wk}$ before experiments. Healthy ICR mice were randomly allocated into 5 groups of 6 male mice each. One group served as a control to orally receive distilled water and the others were administered BC703 (0, 1 and $5 \mathrm{mg} / \mathrm{kg}$ bodyweight) and digested BC703 with simulated gastric juice (10 mg as BC703/ $\mathrm{kg}$ bodyweight) for 3 consecutive days. At $3 \mathrm{~h}$ after the last treatment, mice were intraperitoneally injected with olive oil or $50 \%$ of $\mathrm{CCl}_{4}(1 \mathrm{~mL} / \mathrm{kg}$ bodyweight in olive oil). After $24 \mathrm{~h}$ of $\mathrm{CCl}_{4}$ administration, surviving mice were killed by cardiac puncture after being anesthetized lightly with carbon dioxide. Collected blood samples were separated by centrifuging at $800 \times g$ for $15 \mathrm{~min}$ and the serum samples were subjected to biochemical investigations. Liver samples from each mouse were removed for histopathological and biochemical examination. The experimental protocols were approved by the Institutional Animal Care and Use Committee of Chungnam National University (Daejeon, Korea).

Serum and hepatic biochemical examination. The serum ALT and AST activities were determined on a dry chemistry system, the Vettest 8008 blood chemistry analyzer (IDEXX Laboratories). The content of malondi- aldehyd (MDA), a terminal product of lipid peroxidation, was measured with the thiobarbituric acid reduction method using a commercially available kit (Quatichrom TBARS assay kit, Bioassay Systems). The hepatic GSH levels were determined using the improved DTNB $\left(5,5^{\prime}\right.$ dithiobis-(2-nitrobenzoic acid)) method (QuantiChrom GSH Assay kit; BioAssay Systems). The hepatic SOD levels were also evaluated using the superoxide dismutase assay kit (Cayman).

Histopathological examination. The liver slices were made from a part of the left lobe and fixed immediately in a $10 \%$ buffered formalin phosphate solution, embedded in paraffin, and sectioned at $5 \mu \mathrm{m}$. The serial sections were stained with hematoxylin and eosin (H\&E) to evaluate the portal inflammation, hepatocellular necrosis and Kupffer cell hyperplasia. To quantify the degree (\%) of hepatic necrosis, liver H\&E sections were digitally photographed, and the percentage of necrotic areas was quantified as the mean of 10 randomly selected fields within each slide.

Statistical analysis. Results were expressed as mean \pm standard error (SE). The significances of differences among experimental groups were determined using one-way analysis of variance (ANOVA) or the corresponding non-parametric Kruskal-Wallis test, as required. Where significant effects were found, post-hoc analysis using Turkey's multiple comparison test or the Mann-Whitney U-test was performed and $p<0.05$ was considered to be statistically significant.

\section{RESULTS}

\section{HPLC-ELSD fingerprint-analysis}

On the basis of fingerprint analysis of BC703, it contained a large group of oleanane-type triterpenoid saponins, such as deapioplatycoside E, platycoside E, platycodin $\mathrm{D}_{3}$, platycodin $\mathrm{D}_{2}$, platycodin $\mathrm{D}$, platycodin $\mathrm{A}$, polygalacin D, 3"-O-acetyl polygalacin D, 2"-O-acetyl platycodin D (Fig. 1). Among these triterpenoid saponins, platycodin D is the major and potent constituent of triterpenoid saponin found in the root of Platycodon grandiflorum. Thus, BC703 was standardized in reference to platycodin D (at least $0.8 \%$ ) using a validated HPLC assay method as previously described (5). A number of other non-saponin chemical constituents have been identified from Platycodon grandiflourm, including 

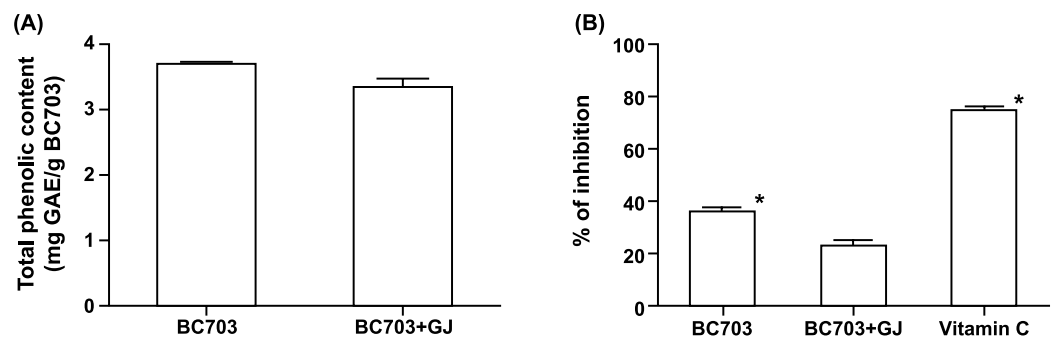

Fig. 2. Total phenolic content and DPPH free radical scavenging activity of BC703. (A) total phenolic content of BC703 before and after gastric digestion with pepsin- $\mathrm{HCl}(\mathrm{pH} 2.0)$ for $2 \mathrm{~h}$ at $37^{\circ} \mathrm{C}$. The total phenolic contents were expressed as $\mathrm{mg}$ of gallic acid equivalent (GAE) per $\mathrm{g}$ of BC703. (B) changes in DPPH free radical scavenging activity of BC703 (500 $\mu \mathrm{g} /$ $\mathrm{mL})$ before and after gastric digestion with pepsin- $\mathrm{HCl}(\mathrm{pH} 2.0)$ for $2 \mathrm{~h}$ at $37^{\circ} \mathrm{C}$. Vitamin $\mathrm{C}(10 \mu \mathrm{g} / \mathrm{mL})$ served as a positive control for DPPH free radical scavenging activity. Values are expressed as means \pm SE. ${ }^{*} p<0.05$, a significant difference in comparison with gastric digestion of $\mathrm{BC} 703(10 \mu \mathrm{g} / \mathrm{mL})$ with pepsin- $\mathrm{HCl}(\mathrm{pH} 2.0)$ for $2 \mathrm{~h}$.

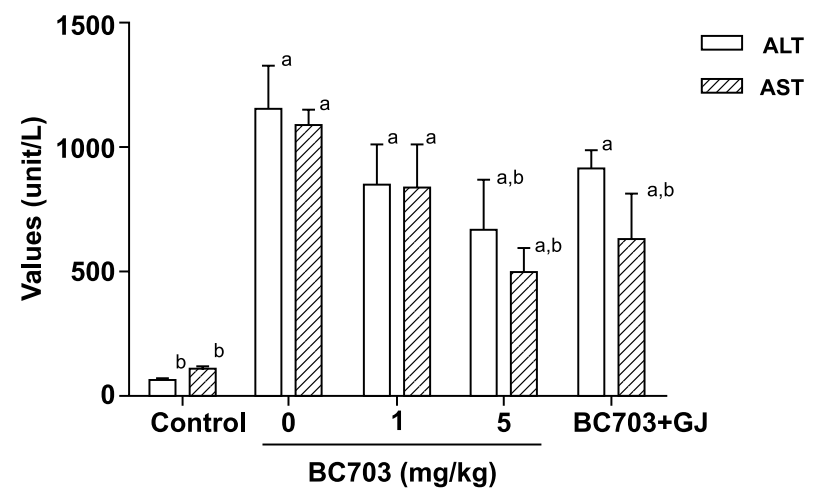

Fig. 3. Effect of $\mathrm{BC} 703$ on liver function in $\mathrm{CCl}_{4}$-induced acute hepatic injury. Mice were given orally $\mathrm{BC} 703(0,1$ and $5 \mathrm{mg} / \mathrm{kg}$ bodyweight) once daily for 3 consecutive days prior to intraperitoneal injection of $50 \% \mathrm{CCl}_{4}(1 \mathrm{~mL} / \mathrm{kg}$ bodyweight in olive oil) or olive oil. Mice in the digested $\mathrm{BC} 703$ with a stimulated gastric juice treated group were given orally digested BC703 (10 mg/kg bodyweight) once daily for 3 consecutive days prior to intraperitoneal injection of $50 \% \mathrm{CCl}_{4}(1 \mathrm{~mL} / \mathrm{kg}$ in olive oil). Values are expressed as means \pm SE (in surviving animals). ${ }^{a} p<0.05$, a significant difference in comparison with the control group. ${ }^{\mathrm{b}} p<0.05$, a significant difference in comparison with the $\mathrm{CCl}_{4}$ alone treated group.

$\alpha$-spinasterol, $\alpha$-spinasteryl- $\beta$-glucoside, stigmasterol, inulin-type polyfructose, and pectin $(22,23)$.

Total phenol content and DPPH radical scavenging activity

The DPPH free radical scavenging activity of $\mathrm{BC703}$ is shown in Fig. 2 and the calculated $\mathrm{EC}_{50}$ of $\mathrm{BC} 703$ was $0.91 \mathrm{mg} / \mathrm{mL}$. Simulated gastric digestion of BC703 with pepsin-HCl ( $\mathrm{pH} 2.0$ ) for $2 \mathrm{~h}$ did not show any difference of phenolic content, whereas DPPH radical scavenging activity was significantly decreased in gastric digestion of BC703 ( $p<0.05$, Fig. 2). Triterpenoids in BC703 after $2 \mathrm{~h}$ of digestion with pepsin under acidic conditions were also slightly decreased to approximately 92.24士 $4.32 \%$ of intact BC703, based on the relative amount of platydodin D.

Hepatoprotective activity of $\mathrm{BC} 703$

BC703 increased the survival rate of mice challenged with a lethal dose of $\mathrm{CCl}_{4}$. After $24 \mathrm{~h}$, viability in the $\mathrm{CCl}_{4}$ alone treated and digested BC703 $(10 \mathrm{mg} / \mathrm{kg}$ bodyweight) treated group was $50 \%$, while that in the BC703 (1 mg/kg and $5 \mathrm{mg} / \mathrm{kg}$ bodyweight) treated group was $66 \%$ and $83 \%$, respectively. In the $\mathrm{CCl}_{4}$ alone treated group, serum ALT and AST were increased as compared to the negative control group $(p<0.05$, Fig. $3)$. The elevated levels of serum ALT and AST were reduced in the group treated with $5 \mathrm{mg} / \mathrm{kg}$ bodyweight of BC703 $(p<0.05)$. Treatment with BC703 decreased ALT and AST levels in $\mathrm{CCl}_{4}$ treated mice in a dosedependent manner (Fig. 3). Similarly, the liver homogenate showed significant reduced activities of GSH and SOD, whereas increased levels of NO and lipid peroxidation were shown in the $\mathrm{CCl}_{4}$ alone treated group (Fig. 4). The administration of BC703 showed an increase in GSH and SOD levels with decreased levels of NO and lipid peroxidation (Fig. 4). BC703 showed hepatoprotective activity in mice with $\mathrm{CCl}_{4}$-induced hepatic injury. However, for digested $\mathrm{BC} 703$ with stimulated gastric juice under acidic conditions for $2 \mathrm{~h}$, the hepatoprotective activity was decreased in the $\mathrm{CCl}_{4}$-induced hepatic injury group as compared to BC703 treated groups.

Histopathological observations

The liver from animals in the negative control group had normal hepatic cells with well-preserved cytoplasm, a prominent nucleus, nucleolus and visible central veins, whereas the liver collected from $\mathrm{CCl}_{4}$-treated mice showed extensive, mainly pericentral necrosis with loss of hepatic architecture, vacuolar fatty change and mild inflammatory cell infiltration comprised predominantly of mononuclear cells and macrophages (Fig. 5). The lower dose of BC703 (1 mg/kg bodyweight) did not prevent the toxic effect of $\mathrm{CCl}_{4}$ with large 
(A)

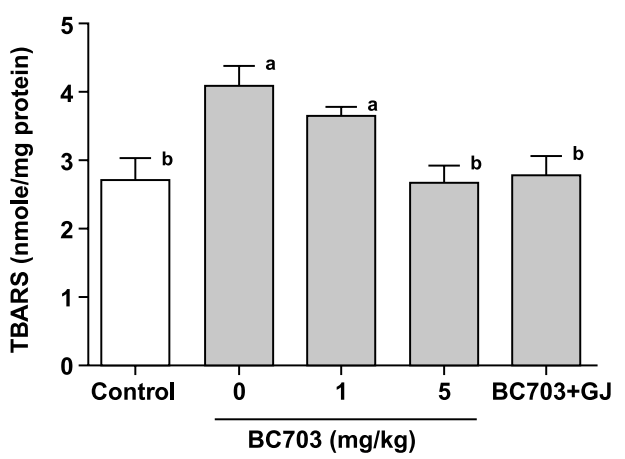

(C)

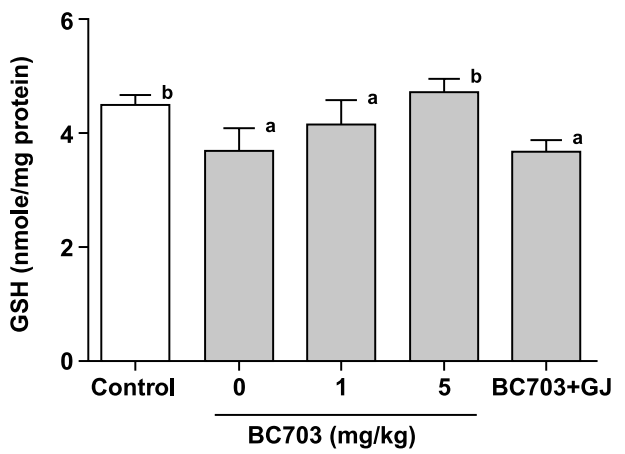

(B)

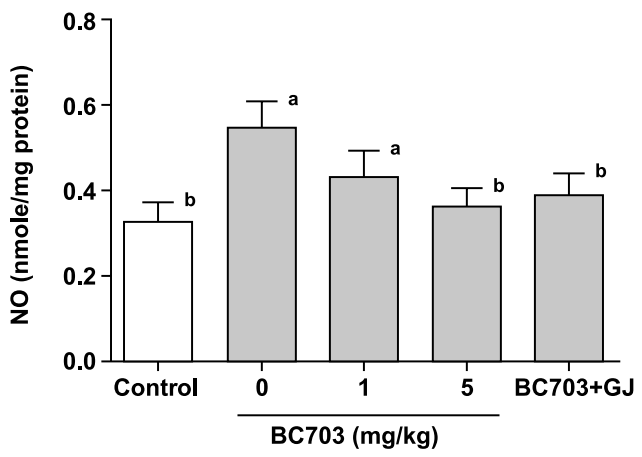

(D)

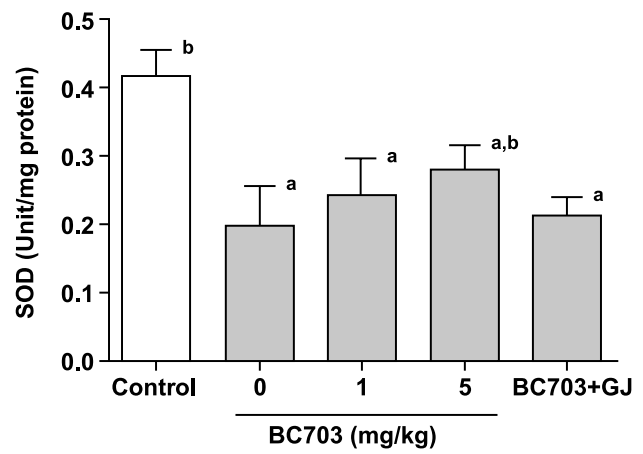

Fig. 4. Effect of BC703 on TBARS (A), NO (B), GSH (C) and SOD (D) content on $\mathrm{CCl}_{4}$-induced acute hepatic injury. Mice were given orally $\mathrm{BC} 703(0,1$ and $5 \mathrm{mg} / \mathrm{kg}$ bodyweight) once daily for 3 consecutive days prior to intraperitoneal injection of $50 \% \mathrm{CCl}_{4}(1 \mathrm{~mL} / \mathrm{kg}$ bodyweight in olive oil) or olive oil. Mice in the digested $\mathrm{BC} 703$ with a stimulated gastric juice treated group were given orally digested BC703 (10 mg/kg bodyweight) once daily for 3 consecutive days prior to intraperitoneal injection of $50 \% \mathrm{CCl}_{4}(1 \mathrm{~mL} / \mathrm{kg}$ bodyweight in olive oil). Values are expressed as means \pm SE (in survival animals). ${ }^{a} p<0.05$, a significant difference in comparison with the control group. ${ }^{\mathrm{b}} p<0.05$, a significant difference in comparison with the $\mathrm{CCl}_{4}$ alone treated group.
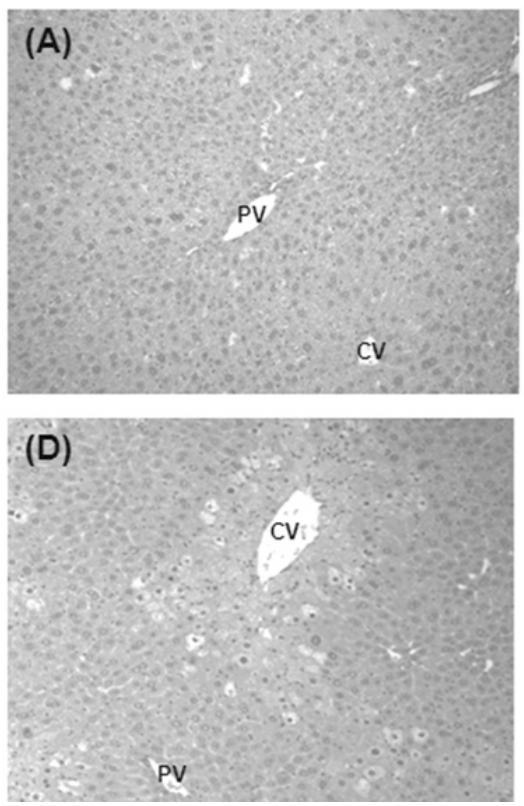
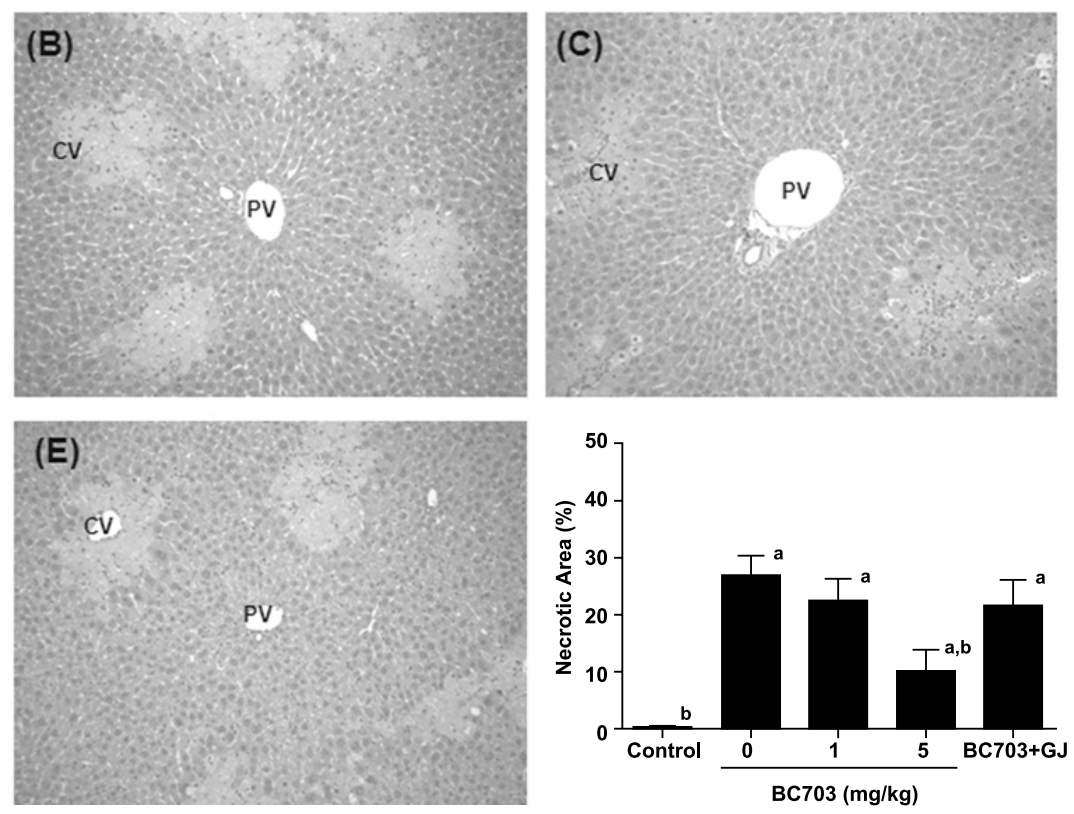

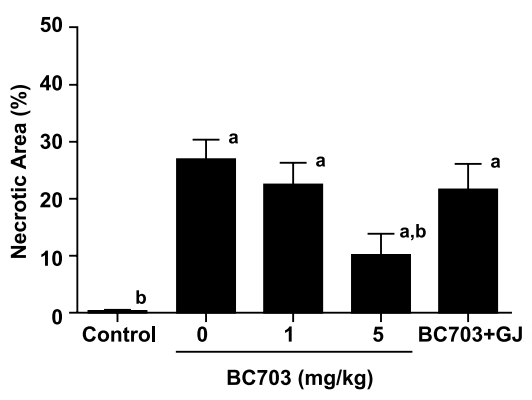

Fig. 5. The histopathological changes in liver stained with hematoxyline \& eosin in $\mathrm{CCl}_{4}$-induced hepatotoxicity $(\times 200)$. Mice were given orally $\mathrm{BC} 703$ ( 0,1 and $5 \mathrm{mg} / \mathrm{kg}$ bodyweight) once daily for 3 consecutive days prior to intraperitoneal injection of $50 \% \mathrm{CCl}_{4}(1 \mathrm{~mL} / \mathrm{kg}$ bodyweight in olive oil) or olive oil. Mice in the digested BC703 with a stimulated gastric juice treated group were given orally digested BC703 $(10 \mathrm{mg} / \mathrm{kg}$ bodyweight $)$ once daily for 3 consecutive days prior to intraperitoneal injection of $50 \% \mathrm{CCl}_{4}(1 \mathrm{~mL} / \mathrm{kg}$ in olive oil $)$. A, non-treated negative control; $\mathrm{B}, \mathrm{CCl}_{4}$ alone treated group; $\mathrm{C}, \mathrm{CCl}_{4}+1 \mathrm{mg} / \mathrm{kg}$ of $\mathrm{BC} 703$ treated group; $\mathrm{D}, \mathrm{CCl}_{4}+5 \mathrm{mg} / \mathrm{kg}$ of $\mathrm{BC} 703$ treated group; $\mathrm{E}, \mathrm{CCl}_{4}+10 \mathrm{mg} / \mathrm{kg}$ of digested BC703 treated group. ${ }^{\mathrm{a}} p<0.05$, a significant difference in comparison with the control group. ${ }^{\mathrm{b}} p<0.05$, a significant difference in comparison with the $\mathrm{CCl}_{4}$ alone treated group. 
(A)

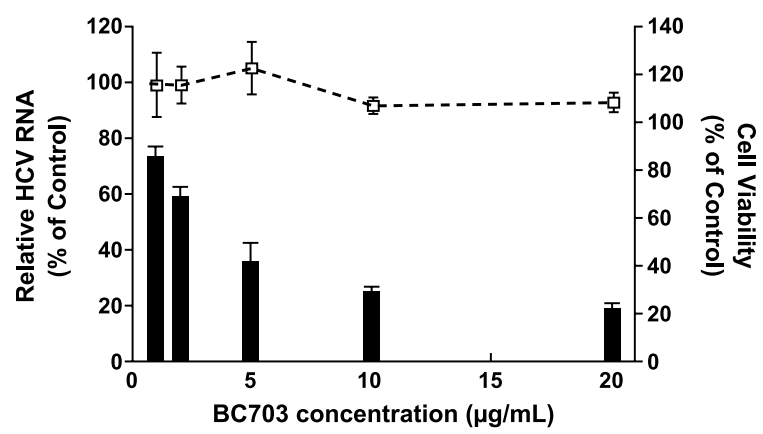

(B)

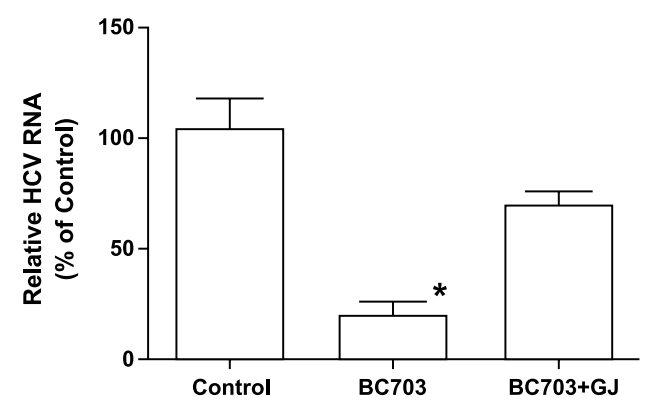

Fig. 6. Suppressive effect of BC703 on HCV RNA replication. Huh7 cells harboring the HCV genotype 1b replicon were treated with different concentrations $(1,2,5,10$ and $20 \mu \mathrm{g} / \mathrm{mL})$ of BC703 (A) before and after simulated gastric digestion of BC703 $(10 \mu \mathrm{g} / \mathrm{mL})$ with pepsin- $\mathrm{HCl}(\mathrm{pH} 2.0)$ for $2 \mathrm{~h}(\mathrm{~B})$. Treatment with $0.1 \%$ DMSO served as a mock control for antiHCV activity. Total RNA of BC703 treated Huh7 cells was extracted to quantify HCV RNA levels by RT-qPCR. Cytotoxicity was simultaneously evaluated by MTT assay. Values are expressed as means \pm SE for triplicate experiments. ${ }^{*} p<0.05$, a significant difference in comparison with gastric digestion of BC703 $(10 \mu \mathrm{g} / \mathrm{mL})$ with pepsin- $\mathrm{HCl}(\mathrm{pH} 2.0)$ for $2 \mathrm{~h}$.

necrotic areas still present. However, the high dose of BC703 ( $5 \mathrm{mg} / \mathrm{kg}$ bodyweight) showed a more or less normal lobular pattern with mild degree of fatty degenerations and necrosis (Fig. 5).

Anti-HCV activity of BC703

The anti-HCV activity of BC703 was evaluated in Huh7 cells harboring the HCV genotype $1 \mathrm{~b}$ replicon. BC703 caused a dose-dependent inhibition of HCV RNA replication without affecting cell viability or cell growth. The calculated $\mathrm{EC}_{50}$ of $\mathrm{BC}_{0} 03$ was $2.82 \mu \mathrm{g} / \mathrm{mL}$ (Fig. 6). However, the anti-HCV activity of digested BC703 with simulated gastric juice significantly decreased $(p<0.05)$. Cytotoxicity of BC703 on Huh7 Cells was also studied. The $\mathrm{CC}_{50}$ value of $\mathrm{BC703}$ was above $100 \mu \mathrm{g} / \mathrm{mL}$ and the selective index $\left(\mathrm{CC}_{50} / \mathrm{EC}_{50}\right)$ of $\mathrm{BC} 703$ in vitro was more than 35.46 .

\section{DISCUSSION}

$\mathrm{CCl}_{4}$ is a well-known model compound for inducing liver injury $(6,7)$. Its biotransformation by the hepatic microsomal cytochrome $\mathrm{P} 450$ produces hepatotoxic metabolites $(8,9)$. The covalent binding of the trichloromethyl free radical to the cell proteins is considered to be the initial step in a chain of events that eventually lead to cell necrosis (10). The results of the present study showed that $\mathrm{CCl}_{4}$ administration caused severe acute liver damage in mice, demonstrated by remarkable elevation of serum AST and ALT levels. The increased serum levels of AST and ALT are attributed to the damaged structural integrity of the liver. Administration of $\mathrm{BC} 703$ prevented $\mathrm{CCl}_{4}$-induced lethality, elevation of ALT, AST and lipid peroxidation in a dosedependent manner, indicating its hepatoprotective effect. These findings were also confirmed by histological observation. The changes mostly included hepatocellular necrosis or apoptosis, fatty accumulation, inflammatory cells in filtration and other histological manifestations, which were also consistent with the findings of other studies $(10,11,24)$.

GSH is the major non-enzymatic antioxidant and regulator of intracellular redox homeostasis, ubiquitously present in all cell types (25). The detoxification mechanism in $\mathrm{CCl}_{4}$-induced hepatotoxicity involves $\mathrm{GSH}$ conjugation of the trichloromethyl radical, a cytochrome P450 2E1-mediated $\mathrm{CCl}_{4}$ metabolite $(8,9)$. $\mathrm{CCl}_{4}$ administration leads to a significant decrease in the glutathione level, which can be an important factor in $\mathrm{CCl}_{4}$ toxicity (25). In addition, lipid peroxidation has been implicated in the pathogenesis of hepatic injury by the free radical derivatives of $\mathrm{CCl}_{4}$ and is responsible for cell membrane damage and the consequent release of marker enzymes of hepatotoxicity $(10,11)$. In this study, pretreatment with $\mathrm{BC} 703$ prior to $\mathrm{CCl}_{4}$-induced hepatic injury inhibited lipid peroxidation and reduced $\mathrm{CCl}_{4}$-induced hepatic GSH depletion, as well as restoring hepatic $\mathrm{Cu} / \mathrm{Zn}$ SOD activities in the liver. A sufficient regenerative response of $\mathrm{BC703}$ by reducing the intensity of liver damage could be also expected.

The current standard care for patients with chronic hepatitis $\mathrm{C}$ is combination therapy with pegylated IFN$\alpha$ and ribavirin (13-15). It is effective in approximately $80 \%$ of patients with HCV genotype 2 or 3 infection, but less than $50 \%$ of patients with HCV genotype 1, by far the most frequent HCV genotype worldwide (14, 15). In addition, the combination therapy is prolonged, costly, and may be associated with adverse effects that are difficult for many patients to tolerate (15). Thus, more effective, more tolerable, and/or more tailored therapies are required.

Numerous studies recently showed that plant extracts exhibit an inhibitory effect on HCV enzyme and replication $(4,16-18,26)$. They have demonstrated their utility in eradicating chronic hepatitis $\mathrm{C}$ through a multitude of hepatoprotective functions in initial trials. Therefore, plant extracts have been considered as potential sources of new bioactive compounds against HCV infection (4, 16-18, 26). Ma et al. (27) reported that 27 of 44 medicinal herbs showed potent or moderate antiviral activities against respiratory syncytical virus (RSV). Among them, Platycodon grandiflorum extract exhibited an inhibitory effect against RSV with an $\mathrm{IC}_{50}$ value of $44.1 \mathrm{mg} / \mathrm{mL}$ an SI index of 8.0 (27). In 
the present study, we showed that BC703 strongly inhibited HCV genotype $1 \mathrm{~b}$ replicon replication in Huh7 cells with an $\mathrm{EC}_{50}$ of $2.82 \mu \mathrm{g} / \mathrm{mL}$ and an SI index of $>35.46$, although the detailed mechanism has not been clearly defined. BC703 may be considered as a potential source of new bioactive compounds against $\mathrm{HCV}$ infection.

There is still debate about the stability and absorption of plant-derived compounds comprising a wide range of bioactive constituents under gastrointestinal conditions. Inulin is a polysaccharide with $\beta$ (2-1) linkages by which D-fructose is polymerized. Inulin is widely distributed throughout the plant kingdom and exists as a reserve substance in the tuber or tuberous roots of plants including Platycodon grandiflorum (22, 23). Plant-origin inulin is resistant to hydrolysis by pancreatic amylase and saccharidase in the upper gastrointestinal tract and it reaches the large intestine unabsorbed and is utilized as a carbohydrate substrate for the growth of indigenous bifidobacteria $(22,23)$. However, from many other studies on the degradation and metabolization of $\beta$-glycosides of plant origin, it is known that the metabolization proceeds mainly via degradation processes already occurring in the gastrointestinal tract $(27,28)$. Moreover, Shimizu et al. reported that saikosaponins in Bupleurum species converted into their corresponding structural isomers of diene derivatives with acidic treatment or in gastric juice with low $\mathrm{pH}$ (29). Under acidic conditions, ginsenoside Re was mainly hydrolyzed to yield $\operatorname{Rg} 2$ and then ginsenoside $\mathrm{Rg} 2$ was transformed to $20(\mathrm{R})-\mathrm{Rg} 2$ by epimerization, or changed to ginsenoside F4 and Rg6 via a dehydration reaction (30). In the present study, the treatment group with digested BC703 using a simulated gastric juice showed poor protective activity against $\mathrm{CCl}_{4}$-induced hepatotoxicity in mice and anti$\mathrm{HCV}$ activity in $\mathrm{HCV}$ genotype $1 \mathrm{~b}$ subgenomic replicon RNA containing Huh7 cells as compared to the BC703. On the basis of these results, active ingredients of BC703 having the anti-HCV and hepatoprotective activity may be not stable in human gastric juice. Thus, BC703 for clinical use in humans may require a specific drug delivery system such as an enteric coated tablet formulation to minimize the degradation of its active ingredient by low gastric $\mathrm{pH}$ and to improve its bioavailability.

In conclusion, $\mathrm{BC} 703$ attenuates the $\mathrm{CCl}_{4}$-induced acute hepatotoxicity in mice and inhibits HCV RNA replication in Huh7 cells harboring the HCV genotype $1 b$ replicon. Although further studies are necessary, BC703 may be a beneficial agent for the management of acute hepatic injury and chronic HCV infection.

\section{Acknowledgments}

This research was supported by iPET (Korea Institute of Planning and Evaluation for Technology in Food, Agriculture, Forestry and Fisheries), Ministry for Food, Agriculture, Forestry and Fisheries, Republic of Korea.

\section{REFERENCES}

1) Lee EB. 1973. Pharmacological studies on Platycodon grandiflorum A. DC. IV. A comparison of experimental pharmacological effects of crude platycodin with clinical indications of platycodi radix (author's transl). Yakugaku Zasshi 93: 1188-1194.

2) Han SB, Park SH, Lee KH, Lee CW, Lee SH, Kim HC, Kim YS, Lee HS, Kim HM. 2001. Polysaccharide isolated from the radix of Platycodon grandiflorum selectively activates B cells and macrophages but not $\mathrm{T}$ cells. Int Immunopharmacol 1: 1969-1978.

3) Kim KS, Ezaki O, Ikemoto S, Itakura H. 1995. Effects of Platycodon grandiflorum feeding on serum and liver lipid concentrations in rats with diet-induced hyperlipidemia. J Nutr Sci Vitaminol 41: 485-491.

4) Lee JC, Chen WC, Wu SF, Tseng CK, Chiou CY, Chang FR, Hsu SH, Wu YC. 2011. Anti-hepatitis C virus activity of Acacia confusa extract via suppressing cyclooxygenase-2. Antiviral Res 89: 35-42.

5) Lim JH, Kim TW, Park SJ, Song IB, Kim MS, Kwon HJ, Cho ES, Son HY, Lee SW, Suh JW, Kim JW, Yun HI. 2011. Protective effects of Platycodon grandiflorum aqueous extract on thioacetamide-induced fulminant hepatic failure in mice. J Toxicol Pathol 24: 223-228.

6) Lee KJ, Choi JH, Kim HG, Han EH, Hwang YP, Lee YC, Chung YC, Jeong HG. 2008. Protective effect of saponins derived from the roots of Platycodon grandiflorum against carbon tetrachloride induced hepatotoxicity in mice. Food Chem Toxicol 46: 1778-1785.

7) Lee KJ, You HJ, Park SJ, Kim YS, Chung YC, Jeong TC, Jeong HG. 2001. Hepatoprotective effects of Platycodon grandiflorum on acetaminophen-induced liver damage in mice. Cancer Lett 174: 73-81.

8) Brautbar N, Williams J. 2002. Industrial solvents and liver toxicity: risk assessment, risk factors and mechanisms. Int J Hyg Environ Health 205: 479-491.

9) Brattin WJ, Glende EA Jr, Recknagel RO. 1985. Pathological mechanisms in carbon tetrachloride hepatotoxicity. J Free Radic Biol Med 1: 27-38.

10) Domitrovic R, Jakovac H, Milin C, Radosevic-Stasic B. 2009. Dose- and time-dependent effects of luteolin on carbon tetrachloride-induced hepatotoxicity in mice. Exp Toxicol Pathol 61: 581-589.

11) McCay PB, Lai EK, Poyer JL, DuBose CM, Janzen EG. 1984. Oxygen- and carbon-centered free radical formation during carbon tetrachloride metabolism. Observation of lipid radicals in vivo and in vitro. $J$ Biol Chem 259: 2135-2143.

12) Recknagel RO, Glende EA Jr, Dolak JA, Waller RL. 1989. Mechanisms of carbon tetrachloride toxicity. Pharmacol Ther 43: 139-154.

13) Alter MJ. 2007. Epidemiology of hepatitis $C$ virus infection. World J Gastroenterol 13: 2436-2441.

14) Feld JJ, Hoofnagle JH. 2005. Mechanism of action of interferon and ribavirin in treatment of hepatitis C. Nature 436: 967-972.

15) Fried MW, Shiffman ML, Reddy KR, Smith C, Marinos G, Goncales FL Jr, Haussinger D, Diago M, Carosi G, Dhumeaux D, Craxi A, Lin A, Hoffman J, Yu J. 2002. Peginterferon alfa-2a plus ribavirin for chronic hepatitis C virus infection. N Engl J Med 347: 975-982.

16) Ikeda K, Arase Y, Kobayashi M, Saitoh S, Someya T, Hosaka T, Sezaki H, Akuta N, Suzuki Y, Suzuki F, Kumada H. 2006. A long-term glycyrrhizin injection 
therapy reduces hepatocellular carcinogenesis rate in patients with interferon-resistant active chronic hepatitis C: a cohort study of 1249 patients. Dig Dis Sci 51: 603-609.

17) Seeff LB, Curto TM, Szabo G, Everson GT, Bonkovsky HL, Dienstag JL, Shiffman ML, Lindsay KL, Lok AS, Di Bisceglie AM, Lee WM, Ghany MG. 2008. Herbal product use by persons enrolled in the Hepatitis C Antiviral Long-Term Treatment Against Cirrhosis (HALT-C) Trial. Hepatology 47: 605-612.

18) Wagoner J, Negash A, Kane OJ, Martinez LE, Nahmias Y, Bourne N, Owen DM, Grove J, Brimacombe C, McKeating JA, Pecheur EI, Graf TN, Oberlies NH, Lohmann V, Cao F, Tavis JE, Polyak SJ. 2010. Multiple effects of silymarin on the hepatitis C virus lifecycle. Hepatology $\mathbf{5 1}$ : 1912-1921.

19) Ikeda M, Yi M, Li K, Lemon SM. 2002. Selectable subgenomic and genome-length dicistronic RNAs derived from an infectious molecular clone of the HCV-N strain of hepatitis C virus replicate efficiently in cultured Huh7 cells. J Virol 76: 2997-3006.

20) Slinkard C, Singleton VL. 1977. Total phenol analysis: Automation and comparison with manual methods American. J Enol Viticult 28: 49-55.

21) Blois MS. 1958. Antioxidant determinations by the use of a stable free radical. Nature 181: 1199-2000.

22) Che YH. 1992. The extract of inulin from Platycodon grandiflorum. J Lanzhou Med Coll 18: 253.

23) Oka M, Ota N, Mino Y, Iwashita T, Komura H. 1992. Studies on the conformational aspects of inulin oligo- mers. Chem Pharm Bull 40: 1203-1207.

24) Comporti M. 1989. Three models of free radical-induced cell injury. Chem Biol Interact 72: 1-56.

25) Valko M, Leibfritz D, Moncol J, Cronin MT, Mazur M, Telser J. 2007. Free radicals and antioxidants in normal physiological functions and human disease. Int $J$ Biochem Cell Biol 39: 44-84.

26) Zuo G, Li Z, Chen L, Xu X. 2007. Activity of compounds from Chinese herbal medicine Rhodiola kirilowii (Regel) Maxim against HCV NS3 serine protease. Antiviral Res 76: $86-92$

27) Ma SC, Du J, But PP, Deng XL, Zhang YW, Ooi VE, Xu HX, Lee SH, Lee SF. 2002. Antiviral Chinese medicinal herbs against respiratory syncytial virus. J Ethnopharmacol 79: 205-211.

28) Tawab MA, Bahr U, Karas M, Wurglics M, Schubert-Zsilavecz M. 2003. Degradation of ginsenosides in humans after oral administration. Drug Metab Dispos 31: 10651071.

29) Shimizu K, Amagaya S, Ogihara Y. 1985. Structural transformation of saikosaponins by gastric juice and intestinal flora. J Pharmacobiodyn 8: 718-725.

30) Kong H, Wang M, Venema K, Maathuis A, van der Heijden R, van der Greef J, Xu G, Hankemeier T. 2009. Bioconversion of red ginseng saponins in the gastrointestinal tract in vitro model studied by high-performance liquid chromatography-high resolution Fourier transform ion cyclotron resonance mass spectrometry. J Chromatogr A 1216: 2195-2203. 